\title{
Reformers in medical education and practice
}

\author{
Martin A Entin MD FRCSC FACS \\ Plastic and Reconstructive Surgery, Royal Victoria Hospital, Montreal, Quebec
}

MA Entin. Reformers in medical education and practice. Can J Plast Surg 2000;8(1):25-29.

BACKGROUND: The standards of professional practice are constantly shifting to keep pace with acquired knowledge. When the standards fell short of professional expectations, when the practising physician became more concerned with financial gain than effective patient care, society needed a reformer to evaluate the process and to improve it.

STUDY DESIGN: Individual physicians and scientists were selected from throughout the history of medicine until the end of the 18th century, who conformed to our definition of reformers, namely, a person who changed the structure or ideology of medical practice. RESULTS: This survey demonstrates that reforms are produced by persons whose minds possess analytical quality and critical judgment. Reformers have influenced the directions of medical practice and teaching.

CONCLUSION: The improvement in medical practice has been achieved through intuitive leaps, rejection of conventional practice, painstaking research or administrative restructuring.

Key Words: Historical perspective; Medical reform

\section{Les réformateurs dans la pratique et l'éducation médicales}

HISTORIQUE : Les normes de la pratique professionnelle varient constamment pour s'adapter aux nouvelles connaissances acquises. Quand les normes étaient en deçà des attentes professionnelles, quand le médecin était plus motivé à gagner de l'argent qu'à réellement soigner ses patients, la société a eu besoin de réformateurs pour évaluer le processus et l'améliorer.

MODÈLE DE L'ÉTUDE : Des individus médecins et scientifiques ont été sélectionnés à travers l'histoire de la médecine jusqu'à la fin du $18^{\mathrm{e}}$ siècle, qui correspondaient à notre définition de réformateurs, à savoir, des personnes qui ont changé la structure ou l'idéologie de la pratique médicale.

RÉSULTATS : Cette enquête démontre que les réformes sont le fruit d'individus dotés d'un esprit d'analyse et d'un jugement critique. Les réformateurs ont influencé le cours de la pratique et de l'enseignement de la médecine.

CONCLUSION : On est parvenu à améliorer la pratique médicale par bonds intuitifs, par le rejet de la pratique conventionnelle, par une recherche minutieuse ou par une restructuration administrative.

$\mathrm{T}$ hroughout the history of medicine, the standards of professional practice were constantly shifting to keep pace with acquired knowledge. Some of the reformers described below established those standards. Occasionally, standards fell short of professional expectations: perhaps teaching programs or instructors did not keep pace with medical progress or perhaps practising physicians were concerned more with financial gain or professional reward than with effective patient treatment or cure. Fortunately, the medical profession

Correspondence and reprints: Dr Martin A Entin, Royal Victoria Hospital, 687 Pine Avenue West, R3.27, Montreal, Quebec H3A 1 A1. Telephone 514-843-1440, fax 514-843-1468 had its fair crop of reformers who altered the way medicine was practised, taught or administered.

I suggest that a reformer is an individual or group who consciously or unconsciously changes the structure or ideology of any facet of the medical profession truly affecting the life of a local or larger society.

One type of medical reform may have as its primary purpose the assessment and evaluation of the system's process, procedures, management or governance and the recommendation of measures to correct, improve or replace the existing system.

Other reformers throughout the period of history of medicine covered in this study were unusually talented persons 
who introduced innovations in medical research or medical philosophy. They are justifiably considered reformers if their discoveries or innovations produced profound changes in the theoretical and practical study of medicine and human disease.

The analysis of the reformers that follows is confined to the history of medicine that extends from antiquity to the emergence of modern science at the end of the 18th century. It begins with Hippocrates and terminates with Morgagni, a span of 2300 years.

\section{HIPPOCRATES (BC 460 to 375)}

In the early stages of human history, knowledge of the healing arts was crucial to the survival of humankind. The concept of illness was psychologically and mythologically tied to the creation of anthropomorphic deities and the notion of punishment. The treatment of illness through the appeasement of the gods was relegated to the shaman or high priest.

In fifth century BC Greece, freedom of thought and intellectual speculation were unfettered. The works of Hippocrates or the Corpus Hippocraticum is generally attributed to several authors rather than to one author named Hippocrates (1). Imbued with a philosophy free of superstition, Hippocrates discarded the prevalent magicoreligious theories and practices. He maintained that disease must be studied as it affects the human body. His observations of the natural course of illnesses revealed that some diseases reach a peak stage and then plateau, maintaining the same crisis level. To keep track of the course of an illness, Hippocrates took a pulse rate and noted the presence of fever and other critical symptoms. Hippocrates also held that good nutrition, fresh air and exercise were necessary to maintain good health (2).

Several aphorisms became poignant expressions of the Hippocratic medical credo, eloquently capturing the essence of the art and science of medicine:

Life is short, the art long, opportunity fleeting, experience treacherous, judgement difficult. The physician must be ready, not only to do his duty himself, but also to secure the cooperation of the patient, of the attendants and of externals (3).

Furthermore, Hippocrates not only created a physicians' guild, securing for them professional dignity and recognition, but also required adherence to the oath binding the physician to a strict code of behaviour.

So profound and lasting were the Hippocratic reforms that the most salient tenets of the oath are still idealistically recited by graduating medical students 2400 years later. Hippocrates oath ingeniously appealed to the physician's natural moral and ethical principles that patients also accepted and trusted implicitly. The doctor-patient bond of trust has become one of society's noblest secular commitments (4).

\section{GALEN (AD 130 to 200)}

The reforms initiated by Hippocrates have influenced the teaching and practice of medicine to this day. His philosophy of medicine prevailed for 500 years until Galen incorporated much of the Hippocratic approach in his own conception of medicine.

Galen's anatomical studies were based on the dissection of animals - mainly hogs and apes. Consequently, his anatomical descriptions of ersatz human anatomy were distortions of actual human anatomy, subsequently accepted by students of Galenic surgery (5). Galen established the general principle that simple assertions were not to be accepted without verifying them with observed facts. The ability to diagnose disease and outline the prognosis was very important to Galen, as it was to Hippocrates. Galen's approach to medicine was also characterized by a focus on treating the causes, not the symptoms of a disease.

Galen introduced the increased use of drugs in medical practice. As a consequence, drug-derivative plants were imported into Greece from all parts of the world. He prescribed different plants as specific remedies and made records of substances that were harmful when applied to a wound (6). Many of his recommended remedies are prescribed to this day. He eschewed preconceived notions in favour of careful observation and sought truth through properly devised research procedures.

By the fourth century, the Galen canon was well established and widely disseminated. However, the Arabic translations of the eighth and ninth centuries, and the Latin translations of the 16th century diminished the original's clarity of thought and exposition. Thomas Linacre (14601524), humanist, physician and founder of the Royal College of Physicians of London, was sufficiently perturbed by these textual problems that he set out to verify the precise meaning of Galen's writings, comparing the original Greek works to the then extant Latin translation. Linacre's Latin translation became the authoritative text that perpetuated Galen's medical philosophy throughout the Early Renaissance (7).

Furthermore, Galen's knowledge of anatomy derived from animal, not human, dissection (which moral and religious precepts forbade) was another source of contention. Because Galen's adherents readily accepted the information contained in his treatises, many errors were perpetuated until Maimonides presented his criticism of Galen's method and Vesalius produced his De humani corpis fabrica in 1543 (8).

Arabian invasion dominated Central Europe from the seventh to the 12th century AD. They discovered and preserved Greco-Roman medicine by translating it into Arabic and disseminated it throughout Europe (9). Arabian scholars are known for preserving knowledge but not for reforming it. Maimonides was the reformer who was trained in the Arabian tradition.

\section{MAIMONIDES (AD 1135 to 1204)}

The religiously tolerant Moors of Cordova had assigned important offices to the followers of other faiths. Consequently, several Spanish Jews who had translated medical treatises into Arabic were encouraged to study the healing arts and to become physicians.

Maimonides was born into a religious Sephardic family of Cordova on March 30, 1135. His mother had died during 
childbirth, and Maimonides was raised by his father who instructed him in the precepts of Judaism (10). The distinguished Arabic scholar Averroes, who was only nine years his senior, taught him philosophy and medicine (11).

In 1148 , Cordova was captured by the militant Almohad Islamic sect. The Maimonides family, disguising their faith, remained in the city until life became intolerable. They moved first to Fez, Morocco in 1158, where Maimonides continued his medical studies that followed the Hippocratic, Galenic and Aristotelian traditions, now translated into the Arabic language (12). In 1165, the family then settled in the old part of Cairo, where Maimonides became a practising physician. His reputation was such that in 1174 he was appointed Court Physician to the Sultan Saladin.

Maimonides accurately described the condition we now recognize as diabetes among his most perceptive medical contributions; he noted the relationship of obstructive emphysema to clubbing of the fingers; he elaborated eight classical signs of hepatitis infection and recorded an accurate description of pneumonia.

Maimonides endeavoured to temper the dogmatic views of his students and eliminate preconceived biases by encouraging them to employ procedures that we have come to associate with the scientific method. He repeatedly admonished his students to evaluate carefully the empirical evidence and urged them to test Galen's hypotheses using the rules of logic (13).

\section{JUAN L VIVES (AD 1492 to 1540)}

During the 13th and 14th centuries, the Bible was considered the source of all wisdom. There was an uncontested faith in Jesus as physician of the soul and body. Advances in the medical sciences were slow and slight. However, in the 15th century the voyages of discovery led to expanded trade and the creation of a new mercantile class ambitious for learning and knowledge. To accommodate this need, universities were founded at Padua, Pavia, Bologna and Oxford. Mathematics, philosophy, logic, botany and medicine were the principal courses offered.

Juan L Vives, born in Valencia in 1492, was the son of a Spanish Jew who converted to Christianity. He was educated at the University of Paris where the humanists Erasmus, Loyola and Rabelais also received their early training. Vives had rejected the profession of priesthood in favour of theology. Early in his career he met Thomas Linacre who was then tutor to Henry VIII. In 1523 Vives dedicated a treatise on the education of Christian women to Queen Catherine, wife of Henry VIII. In appreciation, the Queen appointed him tutor to her daughter Mary Tudor. That same year Cardinal Wolsey obtained a lectureship for Vives at the newly established Corpus Christi College at Oxford.

A profound dissatisfaction with the quality of medical care compelled Vives to take an interest in medical education and launch a single-handed reform of medical education and practice (14). He believed that the quality of medical practice could be improved through a more judicious and stringent screening of applicants to medical schools, and he valued classical education as a necessary prerequisite to the study of medicine (14).

Vives recommended a reform of the curriculum, and proposed the use of new textbooks and a revision of the study of human anatomy and physiology, incorporating the most recent discoveries in pathology and therapeutics. Vives suggested that clinical training be effected through apprenticeships to experienced physicians or through contact with patients 'at the bedside' in hospitals (14).

Vives' interest in public health extended to the care of the poor, whose welfare had traditionally been administered by the church and the monastic orders. Vives believed that the poor should be the responsibility of national and municipal governments.

Vives' reformist vision was prophetic (15). There is some suggestion that a draft for a 'poor relief bill' introduced in the British Parliament in 1535 had some provisions similar to the ideas described in Vives' treatises, and the earliest documented suggestion that the poor be cared for as a civic, not religious, obligation has been attributed to Vives (14). In 1545, the Lord Mayor of London established a plan for the care of the poor that was similar to the propositions elaborated by Vives.

Although Vives was not a physician, his proposals for medical reform were no less valid than those of Abraham Flexner (16) three centuries later.

\section{ANDREAS VESALIUS (AD 1514 to 1564)}

Despite religious opposition to human dissection, Vesalius published an elegant text on human anatomy complemented by illustrative drawings executed by a pupil of Titian, Jan Stephan Van Calcar $(17,18)$. The Latin text was complemented by meticulous descriptions of human anatomy. The Fabrica, as it came to be called, was the product of four years of concentrated, intensive research at the University of Padua (19).

Before Vesalius' work, Galen's text, fraught with errors of translation and interpretation, was used in the instruction of anatomy. As the text was read aloud, the surgeons would dissect the cadaver and demonstrate the specific parts. The Fabrica, containing 663 folio pages of magnificent drawings, was completed in 1543 and became an immediate 'classic'. The precise details of financing the publication are not known, but it has been suggested that Calcar, the artist, paid for the striking of the plates and the copyright (20). In addition to the illustrations, it was the rhetorical elegance and grammatical precision of the Latin that distinguished Fabrica from other medical texts of the time. Fisch (21) has called Vesalius' Fabrica "the manifesto of educational reform".

The powerfully positioned and threatened supporters of Galenic medicine considered Vesalius' work slanderous (22). Discouraged, Vesalius left Padua and became physician to the Court of Charles V of Germany and the Holy Roman Empire. In 1564, while on pilgrimage to Jerusalem, he received an invitation from the University of Padua to replace Gabriel Fallopius as professor of anatomy. Unfortunately, 
his ship was caught in a storm and drifted for weeks. Vesalius took ill and died. He is said to have been buried on the small island of Zante, off the coast of Greece.

Who could imagine to what level of reform Vesalius would have risen if he had replaced Gabriel Fallopius as professor of anatomy.

\section{WILLIAM HARVEY (AD 1578 to 1657)}

Harvey set out to solve the mysteries of the heartbeat and arterial pulsations through the study of the physiology of small animals. In what has become a classical scientific experiment, Harvey (23) proved that the heart is a muscular pump. Galenic medicine distinguished two types of blood or blood sources: the blood of arteries and ventricles, and the blood of veins. The 'spiritual' blood was thought to nourish delicate and light organs, such as the lungs. The venous blood was thought to nourish the heavy organs, such as the liver (24). It was thought that a small part of venous blood passed through invisible pores in the muscular septum of the left ventricle.

Harvey's discovery had a profound reformist impact in establishing the basic physiological principles: he discovered that the heart is a 'pump' propelling blood throughout the arterial system and the lungs; the blood returned to the heart through the venous system. Harvey measured the capacity of the heart to be 56.8 to $85.2 \mathrm{~mL}$. He calculated that with 72 beats $/ \mathrm{min}$, the heart forced $2453.76 \mathrm{~L}$ through the system per hour, and he demonstrated that blood flows from the left ventricle through the lungs. There it is oxygenated and returns to the right ventricle, where other veins draw blood from the periphery of the body (25).

Harvey began his college studies in Cambridge in 1594. After graduating in Arts in 1597, he studied medicine in Padua, receiving his medical degree in 1602 . On his return to England in 1607, he became a Fellow of the Royal College of Physicians (24). In 1642, the year of Galileo's death and of Newton's birth, he was physician to Charles I of Britain at the Battle of Edgehill and was tending to the wounded (24).

In spite of a busy and productive life, Harvey had doubts about his contributions to medicine and society. He need not have doubted. The coat of arms of the Royal College of Physicians of London shows the hand of a physician taking the pulse of a patient, thus immortalizing Harvey's historic discovery. His reforming ideas engendered the study of human physiology.

\section{GIOVANNI BATTISTA MORGAGNI}

(AD 1682 to 1771)

Within a span of 150 years, three reformers advanced medical science through their publications: Vesalius' Fabrica, Harvey's De Mortu Cordis and Morgagni's De Sedibus (26).

Morgagni maintained that disease originates in the local disturbance of an individual organ. Galen also sought to comprehend the disease processes but could not do so without pathological analysis. Morgagni provided that analysis.

Giovanni Morgagni was born in Forli near Bologna on February 25, 1682. He studied medicine at Bologna under the famous anatomist Antonio M Valsalva, a pupil of the famous
Marcello Malpighi. At the completion of his studies in 1709, Morgagni returned to his home town to practise medicine. He was invited to Padua in 1715 as professor of anatomy.

Morgagni was able to combine his superior knowledge of anatomy with clinical practice and the study of pathology. Morgagni is considered the founder of pathological anatomy because he established a new approach to understanding the process of disease through the correlation of the clinical manifestation of the disease with the concurrent pathological changes in the affected organs. De Sedibus comprised five parts including a comprehensive index. It is an encyclopedic reference book serving as a diagnostic aid permitting the correlation of clinical symptoms with pathological findings and vice versa.

Morgagni established the anatomical distinction between the normal and diseased organ, and his wealth of clinical observation and experience led him to demonstrate that a change in the function of organs corresponds to an "anatomical alteration of the organs" (27).

Virchow has stated:

it is clear that only after Morgagni did the clinic attain its true importance, only through and by Morgagni was the dogmatism of the old schools completely shattered and that with him the new medicine begins (28).

\section{CONCLUSION}

Medical reform is most generally associated with discovery or innovation. However, the reform itself - the divergence or shift in thought or practice - is the result of a radical way of thinking, of a reassessment of the system, of ideas that are nontraditional or against convention. Hippocrates' contribution is taken for granted, but his iconoclastic leap in thought and its repercussions are profound as the shift from the Copernican to the Galilean universe. This essay presents the contributions of medical reformers who have altered the direction of medical thinking to the end of the 18th century. Other reformers whose idease have evolved since that time present a challenge for future studies.

\section{REFERENCES}

1. Sigerist HE. Hippocrates and the collection of Hippocratic writings. In: A History of Medicine, vol 2: Early Greek, Hindu and Persian Medicine. New York: Oxford University Press, 1961:260-95.

2. Longrigg J. Greek Rational Medicine. London: Routledge, 1993:83.

3. Jones WHS. Hippocrates with an English Translation, vol 4. New York: YP Putnam, 1923:99.

4. Jones WHS. Hippocrates with an English translation, vol 1:299,301.

5. Temkin O. Galenism: Rise and Decline of a Medical Philosophy. New York: Cornell University Press, 1973:114-5, 141-2.

6. Sarton G. Galen of Pergamon. Lawrence: University of Kansas Press, 1954:64-5.

7. O’Malley CD. English Medical Humanists: Thomas Linacre and John Caius. Lawrence: University of Kansas Press, 1965:13-8.

8. Riese W. The structure of Galen's diagnostic reasoning. Acad Med 1968;44:778-91.

9. Shahine YA. The Arab Contribution to Medicine (Carreras Arab Lecture, 1971). London: Longman for the University of Essex, 1976:9.

10. Rosner F. Moses Maimonides (1135-1204). Ann Intern Med 1965;62:373-5. 
11. Averroes. Tahafut Al-tahafut; The Incoherence of the Incoherence. Translated from the Arabic with introduction and notes by Simon Van den Bergh. London: Oxford University Press, 1954.

12. Leiber E. Galen: Physician as philosopher. Maimonides: Philosopher as Physician. Bull Hist Med 5 1979;53:278.

13. Maimonides M. Maimonides' Medical Writings: Moses Maimonides' Three Treatises on Health; translated and annotated by Fred Rosner. Haifa: The Maimonides Research Institute, 1990:60-1.

14. Travill AA. Juan Luis Vives: A Humanistic Medical Educator. Can Bull Med Hist 1987;4:53-76.

15. Vives JL. De subventions pauperum sive necessitates humani. Bruges, 1526. Translated into English by Sherwood MM under the title Concerning the Relief of the Poor or Concerning Human Need. Studies in Social Work, No 4. New York: New York School of Philanthropy, 1917:48.

16. Flexner A. Medical Education in the United States and Canada; A Report to the Carnegie Foundation for the Advancement of Teaching. Carnegie Foundation for the Advancement of Teaching, Bulletin No 4. New York: The Carnegie Foundation, 1910

17. Vesalius A. De Humani Corpis Fabrica. Basileae: J Oporini, 1543.

18. Petruccelli RJ. Qiorgio-Vasarils attribution of the Vesalian illustrations to Jan Stephan of Calcar: A further examination. Bull Hist Med 1971;45:29-37.

19. Ivins WM. What about the Fabrica of Vesalius. In: Lambert SW,
Wiegard W, Ivins W Jr, eds. Three Vesalian Essays to Accompany the Icones Anatomicae of 1934. New York: The Macmillan Company, 1952:76

20. Singer C. Some Vesalian problems. Bull Hist Med 1945;17:434-5.

21. Fisch M. Vesalius and his book. Bull Med Lib Assoc 1943;31:216.

22. Saunders JB de CM, O'Malley CD. The Illustrations from the Works of Andreas Vesalius of Brussels, with annotations and translations and a biographical sketch of Vesalius. New York: Dover Publications, 1950:31,33.

23. Harvey W. Enercitatio Anatomica de Motu Cordis et Sanguinis in Animalbilus. Frankfurt: William Fitzer, 1628.

24. Chauvais L. William Harvey: His Life and Times: His Discoveries: His Methods. London: Hutchinson Medical Publications, 1957:186.

25. Harvey William. Exercitatio anatomica de motu cordis et sanguinis in animalibus; an English translation with annotations by Chauncey D. Leake. Springfield: Charles Thomas, 1930:73-81.

26. Morgagni GB. De Sedibus et Causis Morborum Per Anatomen Indagatis. Venetiis, 1761. The Seats and Causes of Diseases Investigated by Anatomy, in five books; translated from the Latin by Benjamin Alexander. New York: Hafner, 1960.

27. Castiglioni A. QB Morgagni and the anatomicopathological conception of the clinic. Proc Roy Soc Med 1939;38:377.

28. Virchow R. Morgagni and the anatomic concept. Bull Hist Med 1939;7:986. 